\title{
USAHA GURU AGAMA ISLAM DALAM MENINGKAT MOTIVASI BELAJAR PAI SISWA DI SMP NEGERI 2 KECAMATAN SEI KANAN KABUPATEN LABUHAN BATU SELATAN
}

Oleh:

\section{Syafnan ${ }^{1}$}

\begin{abstract}
Skripsi ini berjudul "Usaha guru Agama Islam dalam meningkatkan Motivasi belajar PAI siswa di SMP Negeri 2 Kecamatan Sei Kanan Kabupaten Labuhan Batu Selatan" Maka masalah yang terdapat dalam penelitian ini adalah adanya siswa yang bolos ketika proses pembelajaran berlangsung, malas mengerjakan tugas, ribut dalam ruangan Dan kurangnya jam mata pelajaran PAI.

Dalam masalah diatas maka penelitian ini bertujuan untuk mengetahui Gambaran yang dilakukan guru Agama Islam dalam meningkatkan motivasi belajar PAI siswa di SMP Negeri 2 Kecamatan Sei Kanan Kabupaten Labuhan Batu Selatan, usaha yang dilakukan guru Agama Islam dalam Menigkatkan Motivasi Belajar PAI siswa di SMP Negeri 2 Keamatan Sei Kanan Kabupaten Labuhan Batu Selatan, dan Hambatan yang dihadapi Guru Agama Islam dalam meningkatkan Motivasi Belajar PAI siswa di SMP Negeri 2 Kecamatan Sei Kanan Kabupaten Labuhan Batu Selatan.

Dalam penelitian ini digunakan penelitian kualitatif dengan menggunakan metode deskriftif yaitu suatu metode yang menggambarkan gejala-gejala yang terdapat di lapangan. Dengan menggunakan instrument pengumpulan data yang terdiri dari observasi, wawancara dan dokumentasi.

Dari hasil peneliti dan pembahasan diperoleh kesimpulan bahwa, Usaha yang dilakukan Guru Agama Islam dalam Meningkatkan Motivasi Belajar PAI siswa di SMP Negeri 2 Kecamatan Sei Kanan Kabupaten Labuhan Batu Selatan adalah memberikan pujian, member ulangan, memberikan angka atau penilaian, mengetahui hasil belajar dan memberikan hukuman. Kemuian hambatan yang dihadapi guru Pendidikan Agama Islam adalah kurangnya jam mata pelajaran, akan tetapi guru Agama Islam berusaha untuk mengoptimalkan waktu yang sedikit itu yaitu dengan diadakannya les
\end{abstract}

${ }^{1}$ Penulis adalah Dosen Fakultas Tarbiyah dan Ilmu Keguruan IAIN Padangsidimpuan 
tambahan satu kali dalam seminggu, kemudian meghadapi siswa yang malas mengerjakan tugas, disinilah hambatan yang paling sulit dihadapi guru Agama Islam tersebut, walaupun demikian guru Agama Islam sabar dalam menghadapi siswa yang tidak mengerjakan tugasnya. Dan ada pula siswa yang ribut ketika proses pembelajaran berlangsung, dan keluar masuk dari ruangan, hal ini merupakan mengganggu konsentrasi pembelajaran siswa tersebut

Keywords: Guru, motivasi belajar, Pendidikan Agama Islam

\section{Latar Belakang Masalah}

Guru adalah sosok yang mengemban tanggung jawab untuk mewujudkan tujuan pendidikan nasional yang berfungsi untuk mengembangkan kemampuan dan membentuk watak serta peradaban bangsa yang bermartabat dalam rangka mencerdaskan kehidupan bangsa, yang bertujuan untuk mengembangkan potensi peserta didik agar menjadi manusia yang beriman, bertakwa pada Tuhan Yang Maha Esa, berakhlak mulia, sehat, berilmu, cakap, kreatif, mandiri, dan menjadi warga negara yang demokrasi dan bertanggung jawab. ${ }^{2}$

Usaha membangkitkan motivasi belajar siswa erat hubungannya dengan kebutuhan siswa, pengetahuannya kemajuan yang diperolehnya dalam kegiatan belajar dan adanya cita-cita (aspirasi). Untuk itu berbagai upaya yang perlu dilakukan untuk meningkatkan motivasi belajar siswa pada bidang studi agama islam tersebut, yaitu dengan mengkaitkan pembelajaran dengan kebutuhan siswa dan menggunakan metode mengajar yang menarik.

Pembelajaran merupakan salah satu wahana yang dapat mempengaruhi pertumbuhan dan perkembangan peserta didik menjadi manusia muslim yang beriman dan bertakwa kepada Allah Swt dan berakhlak mulia. ${ }^{3}$ Dalam hal ini penulis menjelaskan bahwa tanpa adanya motivasi dalam proses pembelajaran yang diberikan guru, anak didik tidak mempunyai semangat untuk mengikuti proses pembelajaran.

Dari realita yang peneliti dapatkan dari lapangan menunjukkan bahwa masih banyak siswa SMP Negeri 2 Kecamatan Sei Kanan Kabupaten Labuhan batu selatan yang kurang termotivasi dalam belajar terhadap materi Pendidikan Agama Islam. Hal ini tampak dari sikap siswa yang malas mengerjakan tugas, bolos

${ }^{2}$ Soetjipto dan Raflis Kosasi, Profesi Keguruan (Jakarta: Rineka Cipta, 2000), hlm. 50.

${ }^{3}$ Azhar Arsyad, Media Pembelajaran (Jakarta: Raja Grafindo Persada,1996), hlm. 2. 
dalampembelajaranberlangsung, ribut ketika berlangsungnya proses pembelajaran Pendidikan Agama Islam. Kemudian kurangnya jam matapelajran Pendidikan Agama Islam. Ini tidak dapat dibiarkan sebab pengajaran Pendidikan Agama Islam di SMP merupakan modal bagi siswa dalam kehidupan beragama selanjutnya. Sementara itu jika dilihat dari metode mengajar, tampaknya guru lebih sering menggunakan metode ceramah, sehingga kegiatan proses belajar mengajar yang dilaksanakan cendrung monoton. Akan tetapi guru Pendidikan Agama Islam juga sering menggunakan metode diskusi dan lainnya, supaya proses pembelajaran tersebut lebih efektif.

Motivasi dapat juga dikatakan serangkaian usaha untuk menyediakan kondisi-kondisi tertentu, sehingga seseorang mau dan ingin melakukan sesuatu, dan bila ia tidak suka, maka akan berusaha untuk meniadakan atau mengelakkan perasaaan tidak suka itu. Jadi motivasi itu dapat dirangsang oleh faktor dari luar, tetapi motivasi itu adalah tumbuh dalam diri seseorang. Dalam kegiatan belajar, motivasi dapat dikatakan sebagai keseluruhan daya penggerak di dalam diri siswa yang menimbulkan kegiatan belajar, yang menjamin kelangsungan dari kegiatan belajar dan yang memberikan arah pada kegiatan belajar, sehingga tujuan yang dikehendaki oleh subjek belajar itu dapat tercapai.

Berdasarkan pengamatan penulis tampak bahwa di SMP Negeri 2 Kecamatan Sei Kanan Kabupaten Labuhan Batu Selatan tersebut guru sudah berusaha untuk memotivasi siswa dalam kegiatan proses pembelajran. Disini yang penulis herankan sebenarnya apa kendala yang dihadapi siswa tersebut sehingga kurang termotivasi dalam proses pembelajaran Pendidikan Agama Islam. Atas dasar inilah peneliti ingin mengadakan suatu penelitian dengan judul "Usaha Guru Agama Islam dalam Meningkat Motivasi Belajar PAI Siswa di SMP Negeri 2 Kecamatan Sei Kanan Kabupaten Labuhan Batu Selatan."

\section{Fokus Masalah}

Berdasarkan uraian di atas, maka yang menjadi batasan masalah dalam penelitian ini adalah Bagaimana usaha guru agama islam dalam Menigkatkan Motvasi Belajar Pendidikan Agama Islam siswa di SMP Negeri 2 Kecamatan Sei Kanan Kabupaten Labuhan Batu Selatan.

\section{Rumusan Masalah}

Berdasarkan Latar belakang masalah diatas permasalahan dalam penelitian ini adalah:

1. Bagaimana gambaran motivasi belajar Pendidikan Agama Islam siswa di SMP Negeri 2 Kecamatan Sei Kanan Kabupaten Labuhan Batu Selatan? 
2. Apa hambatan-hambatan yang dihadapi guru Agama Islam dalam meningkatkan motivasi belajar siswa Pendidikan Agama Islam di SMP Negeri 2 Kecamatan Sei Kanan Kabupaten Labuhan Batu Selatan?

3. Apa usaha yang dilakukan guru Agama Islam dalam meningkatkan motivasi belajar Pendidikan Agama Islam siswadi SMP Negeri 2 Kecamatan Sei Kanan Kabupaten Labuhan Batu Selatan?

\section{Tinjauan Pustaka}

\section{Guru Pendidikan Agama Islam}

\section{a. Pengertian Guru}

Guru adalah orang yang memberikan ilmu pengetahuan kepada anak didik. Guru dalam pandangan masyarakat adalah orang yang melaksanakan pendididkan di tempat-tempat tertentu, tidak mesti di lembaga pendidikan formal, tetapi bisa juga di mesjid, di surau/musalla, dan sebagainya. ${ }^{4}$ Guru memang menempati kedudukan yang terhormat di masyarakat. Kewibawaanlah yang menyebabkan guru dihormati, sehingga masyarakat tidak meragukan figur guru. Masyarakat yakin bahwa gurulah yang dapat mendidik anak didik mereka agar menjadi orang yang berkepribadian mulia. Dengan demikian dapat disimpulkam bahwa guru adalah semua orang yang bertanggung jawab untuk membimbing dan membina anak didik, baik secara individual maupun klasikal, disekolah maupun di luar sekolah. ${ }^{5}$ Dengan kemuliannya, guru rela mengabdikan diri didesa terpencil sekalipun. dengan segala kekurangan yang ada guru berusaha membimbing dan membina anak didik agar menjadi manusia yang berguna bagi nusa dan bangsanya dikemudian hari. Gaji yang kecil, jauh dari memadai, tidak membuat guru berkecil hati dengan sikap frustasi meninggalkan tugas dan tanggung jawab sebagai guru. Karenanya sangat wajar dipundak guru diberikan atribut sebagai " pahlawan tanpa tanda jasa", Sedangkan guru agama islam adalah guru yang mengajar mata pelajaran agama. ${ }^{6}$ Dalam Al- Qur'an Surat Al- Ahzab ayat 21 dijelaskan :

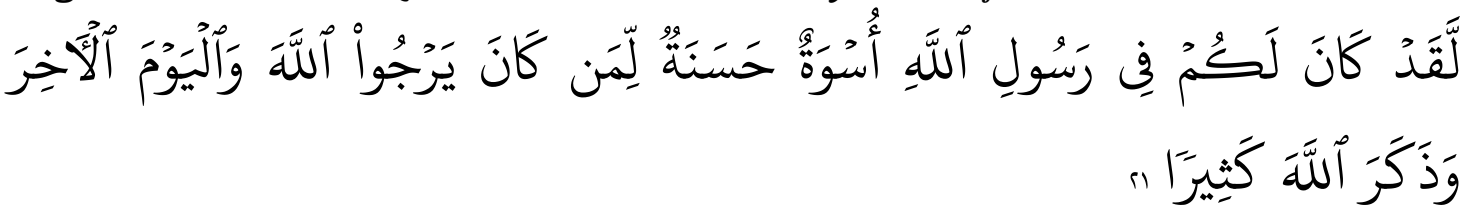

${ }^{4}$ Syaiful Bahri Djamarah, Guru dan Anak Didik dalam Interaksi Edukatif (Jakarta: PT. Asdi Mahasatya, 2005), hlm. 31.

${ }^{5}$ Ibid., hlm. 31-32.

${ }^{6}$ Pusat Bahasa Departemen Pendidikan Nasional, Kamus Besar Bahasa Indonesia Edisi Ke 3 (Jakarta: Balai Pustaka, 2001), hlm. 1180. 
Artinya: "Sesungguhnya telah ada pada (diri) Rasulullah itu suri teladan yang baik bagimu (yaitu) bagi orang yang mengharap (rahmat) Allah dan (kedatangan) hari kiamat dan dia banyak menyebut Allah". 7

Berdasarkan firman di atas dapat diketahui bahwa Rasulullah SAW adalah uswah bagi seluruh umat. Demikian halnya seorang guru diharapkan mampu menjadi uswah bagi siswanya. Dari uraian diatas dapat diketahui bahwa guru merupakan figur pemimpin yang bermoral dan ilmu pengetahuan. Guru sebagai tenaga pengajar yang berusaha melakukan perubahan terhadap anak didik.

b. Kualitas Guru Agama

Tugas guru Agama itu berat, karena di samping membentuk pribadi peserta didik, ia pun harus memperbaiki mana yang kurang baik pada mereka, karena anak didik datang ke sekolah telah membawa berbagai nilai dan pengalaman keagamaan yang diperolehnya dari orang tuanya masing-masing. Ada yang sudah baik, tapi ada yang kurang, bahkan mungkin ada yang tidak baik sama sekali, sesuai dengan keadaan orang tuanya masing-masing. ${ }^{8}$

Karena itu guru Agama masuk ke dalam kelas dengan segala apa yang ada padanya. Cara berpakaian, berbicara, bergaul, bahkan caranya berjalan, makan, minum, duduk dan diamnya, semuanya ikut menunjang keberhasilannya dalam melaksanankan tugas pendidikan Agama bagi peserta didik.

c. Tugas Guru pendidikan Agama Islam

Ramayulis mengemukakan tugas guru pendidikan agama islam yaitu:

1) Tugas secara umum, adalah Sebagai "warasat al- anbiya", yang pada hakikatnya mengemban misi rahmat lil al- alamin, yakni suatu misi yang mengajak manusia untuk tunduk dan patuh pada hukum-hukum Allah, guna memperoleh keselamatan dunia dan akhirat. Kemudian misi ini dikembangkan pembentukan kepribadian yang berjiwa tauhid, kreatif, beramal saleh dan bermoral tinggi.

2) Tugas secara khusus, adalah :

a) Sebagai pengajar (instruksional) yang bertugas merencanakan program pengajaran dan melaksanakan program yang telah disusun, dan penilaian setelah program itu dilaksanakan.

\footnotetext{
${ }^{7}$ Tim Penyusun, Al-Qur'an dan Terjemahannya (Departemen Agama RI), hlm. 670.

${ }^{8}$ Zakiah Darajat, Pendidikan Islam dalam Keluarga dan Sekolah (Jakarta: PT Remaja Rosdakarya, 1994), hlm. 99.
} 
b) Sebagai pendidik (educator) yang mengarahkan peserta didik pada tingkat kedewasaan yang berkepribadian, seiring dengan tujuan Allahmenciptakan Manusia.

c) Sebagai pemimpin (managerial), yang memimpin dan mengendalikan diri sendiri, peserta didik dan masyarakat yang terkait. Menyangkut upaya pengarahan, pengawasan, pengorganisasian, pengontrolan, partisipasi atas program yang dilakukan itu. ${ }^{9}$

\section{Motivasi siswa belajar PAI}

a. Pengertian Motivasi

Motivasi berasal dari bahasa inggris kata motivate- motivation. ${ }^{10}$ Motivate artinya mendorong, menyebabkan kemudian menjadi motivation berarti pengalasan daya batin, dorongan, motivasi. ${ }^{11}$ Dengan motivasi dimaksud usahausaha untuk menyediakan kondisi- kondisi sehingga anak itu mau, ingin melakukannnya. Oemar malik mendefenisikan motivasi adalah suatu proses menentukan karakteristik berdasarkan petunjuk-petunjuk tingkahlaku seseorang. ${ }^{12}$

Menurut Mc. Donald, motivasi adalah perubahan energi dalam diri seseorang yang ditandai dengan munculnya "feeling" dan didahului dengan tanggapan terhadap adanya tujuan. Dari pengertian yang dikemukakan Mc. Donald ini mengandung tiga elemen penting sebagai berikut:

1) Bahwa motivasi itu mengawali terjadinya perhubungan energi pada diri setiap individu manusia. Perkembangan motivasi akan membawa beberapa perubahan energi di dalam sistem "neurophysiological" yang ada pada organisme manusia. Karena menyangkut perubahan energi manusia (walaupun motivasi itu muncul dari dalam diri manusia), tampaknya akan menyangkut kegiatan fisik manusia.

2) Motivasi ditandai dengan munculnya, rasa/"feeling", afeksi seseorang.dalam hal ini motivasi relevan dengan persoalan-persoalan kejiwaan, afeksi dan emosi yang dapat menentukan tingkah laku manusia.

3) Motivasi akan dirangsang karena adanya tujuan. Jadi motivasi dalan hal ini sebenarnya merupakan respon dari suatu aksi, yakni tujuan. Motivasi dari

${ }^{9}$ Ramayulis, Ilmu Pendidikan Islam (Jakarta: Kalam Mulia, 2008), hlm. 63.

${ }^{10}$ AS. Hornby, Oxfordlearnes Pocket Dictionary (New York: Oxford University Press, 1995), hlm. 758 .

${ }^{11}$ Jhon, M. Echols dan Hasan Shadaly, Kamus Inggris Indonesia (Jakarta: Gramedia Pustaka Utama 1986), hlm. 386.

${ }^{12}$ Oemar Hamalik, Kurikulum dan Pembelajaran (Bandung : Bumi Aksara, 2008), hlm. 106. 
dalam diri manusia, tetapi kemunculannyan karena terangsang/ terdorong oleh adanya unsur lain, dalam hal ini adalah tujuan. Tujuan ini akan menyangkut hal kebutuhan. ${ }^{13}$

Dengan ketiga elemen di atas, maka dapat dikatakan bahwa motivasi itu sebagai sesuatu yang kompleks. Motivasi akan menyebabkan terjadinya suatu perubahan energi yang ada pada diri manusia, sehingga akan menyangkut dengan persoalan gejala kejiwaan, perasaan dan juga emosi, untuk kemudian bertindak atau melakukan sesuatu. Semua ini didorong karena adanya tujuan, kebutuhan atau keinginan.

b. Fungsi Motivasi

Setiap motivasi bertalian erat dengan suatu tujuan. Aktivitas itu mempunyai tiga fungsi sebagai berikut:

1) Mendorong manusia untuk berbuat, jadi sebagai penggerak atau motor yang melepaskan energi.

2) Menentukan arah perbuatan, yakni ke arah tujuan yang hendak dicapai.

3) Men-seleksi perbuatan, yakni menentukan perbuatan apa-apa yang harus dijalankan yang serasi guna mencapai tujuan itu. Dalam bahasa sehari-hari motivasi dinyatakan dengan: hasrat, keinginan, maksud, tekad, kemauan, dorongan, kebutuhan, kehendak, cita-cita, dan sebagainya. ${ }^{14}$

c. Macam-macam Motivasi

Macam-macam atau jenis motivasi dapat dilihat dari berbagai sudut pandang. Dengan demikian, motivasi atau motif-motif yang aktif itu sangat bervariasi. Macam-macam motivasi itu sebagai berikut :

1) Motivasi dilihat dari dasar pembentukannya.

a) Motif motif bawaan

Motif bawaan ini ialah motif yang dibawa sejak lahir, jadi motivasi itu ada tanpa dipelajari.

b) Motif-motif yang dipelajari

Motif-motif yang dipelajari ini ialah motif-motif yang timbul karena dipelajari.

2) Motivasi Jasmaniah dan Rohaniah

Ada beberapa ahli yang menggolongkan jenis motivasi itu menjadi dua jenis yakni motivasi jasmaniah dan rohaniah. Yang termasuk motivasi jasmaniah yaitu: reflex, insting otomatis, nafsu. Sedangkan motivasi rohaniah itu adalah

\footnotetext{
${ }^{13}$ Sardiman, Interaksi Motivasi Belajar Mengajar (Jakarta: Rajawali Pres, 2009), hlm.73-74.

${ }^{14}$ S. Nasution, Didaktik Asas- asas Mengajar (PT: Jemmars Bandung 1982), hlm.79-80.
} 
kemauan, maksudnya disini kemauan yang datang dari diri seseoarng tersebut untuk melakukan suatu pekerjaan tersebut atas kemaun dirinya sendiri.

3) Motivasi instrintik dan ekstrinsik

a) Motivasi Instrinsik

Motivasi instrinsik ini adalah motif-motif yang aktif dan berfungsinya tidak perlu dirangsang dari luar, karena dalam diri setiap individu sudah ada dorongan untuk melakukan sesuatu. Sebagai contoh seseorang yang gemar membaca, tidak usah ada yang menyuruh atau mendorongnya, ia sudah rajin mencari buku untuk dibacanya. Kemudian kalau dilihat dari segi tujuan kegiatan yang dilakukannya (misalnya kegiatan belajar), maka yang dimaksud motivasi instrinsik ini adalah ingin mencapai tujuan yag terkandung didalam perbuatan belajar itu sendiri.

b) Motivasi ekstrinsik

Motivasi ekstrinsik adalah motif-motif yang aktif dan berfungsinya karena adanya perangsang dari luar. Sebagai contoh seseorang itu belajar, karena tahu besok paginya akan ujian dengan harapan mendapatkan nilai yang baik, sehingga akan dipuji oleh pacarnya, atau temannya. Jadi yang penting bukan karena ingin belajar mengetahui sesuatu, tetapi ingin mendapatkan nilai yang baik, atau agar mendapat hadiah. Jadi kalau dilihat dari segi tujuan yang dilakukannya, tidak secara langsung bergayut dengan esensi yang dilakukannya itu. ${ }^{15}$

Jadi kedudukan motivasi dalam belajar tidak hanya memberikan arah kegiatan Belajar secara benar,lebih dari itu dengan motivasi seseorang akan mendapat pertimbangan-pertimbangan positif dalam kegiatannya termasuk kegiatan belajar. Usaha Yang dilakukan Guru untuk Memotivasi Siswa dalam belajar.

\section{Belajar Pendidikan Agama Islam}

a. Pengertian Belajar

Belajar adalah syarat mutlak untuk menjadi pandai dalam semua hal, baik dalam hal ilmu pengetahuan maupun dalam bidang keterampilan atau kecakapan.

Menurut para ahli belajar ialah suatu proses usaha yang dilakukan individu untuk memperoleh suatu perubahan tingkah laku yang baru secara

${ }^{15}$ Sardiman, Op.Cit., hlm. 86-89. 
keseluruhan, sebagai hasil pengalaman individu itu sendiri dalam interaksi dengan lingkungannya. Ciri-ciri kematangan belajar itu adalah sebagai berikut:

1) Aktivitas yang menghasilkan perubahan pada diri individu yang belajar, baik aktual, maupun potensial.

2) Perubahan itu pada dasarnya berupa didapatkannya kemampuan baru yang berlaku dalam waktu yang relativ lama.

3) Perubahan itu terjadi karena usaha. ${ }^{16}$

Dari beberapa pengertian tentang belajar dan yang dikemukakan para ahli bahwa belajar itu bertujuan untuk mengadakan perubahan. Jelasnya belajar itu dapat disimpulkan yaitu :suatu usaha atau kegiatan yang bertujuan untuk mengadakan perubahan di dalam diri seseorang, mencakup: perubahan tingkah laku, sikap, kebiasaan, ilmu pengetahuan, keterampilan dan sebagainya.

b. Pengertian pendidikan agama islam

Pendidikan islam adalah pendidikan yang secara aktif menumbuh kembangkan seluruh potensi manusia baik potensi jasmaniah maupun potensi rohaniah. ${ }^{17}$ Dalam defenisi lain dapat diartikan pendidikan islam adalah sebagai usaha sadar yang dilakukan oleh mereka yang memiliki tanggung jawab terhadap pembinaan, bimbigan, pengembangan serta pengarahan potensi yang dimiliki anak agar mereka dapat berfungsi dan berperan sebagai hakikat kejadiannya.

Maka pendidikan islam pada dasarnya adalah pada rumah tangga itu, maka paraorang tua dan para guru dalam pendidikan islam berfungsi dan berperan sebagaipembina, pembimbing, pengembang serta pengarah potensi yang dimiliki anak agar mereka menjadi pengabdian Allah yang taat dan setia, sesuai dengan hakikat penciptaan manusia. Dan juga dapat berperan sebagai Khalifah Allah dalam kehidupan di dunia. Pendidikan seperti itu diterapkan sejak usia bayi dalam buaiyan hingga ke akhir hayat. ${ }^{18}$

\section{Waktu dan Lokasi Penelitian}

Penelitian ini dilakukan di SMP Negeri 2 Kecamatan Sei Kanan Kabupaten Labuhan Batu Selatan, yaitu terletak di desa Sampean,sekitar $12 \mathrm{Km}$ dari Kantor Camat Kecamatan Sei Kanan Kabupaten. Labuhan Batu Selatan.

\footnotetext{
${ }^{16}$ Mardianto, Op.Cit., hlm. 38-39.

${ }^{17}$ Baharuddin, Aktualisasi Psikologi Islam (Yogyakarta: PT. Pustaka Pelajar, 2005), hlm.

${ }^{18}$ Jalaluddin, Psikologi Agama (Jakarta: PT. Raja Grafindo Persada, 2010), hlm.19.
} 133. 
Pemilihan lokasi penelitian adalah mengingat sekolah tersebut adalah merupakan SMP Negeri yang kedua yang ada di Kecamatan Sei Kanan Kabupaten Labuhan Batu, Maka dari itu Peneliti tertarik Untuk menelitinya.

Penelitian ini dilakukan pada bulan November 2014 sampai bulan Oktober 2015 di SMP Negeri 2 Kecamatan Sei Kanan Kabupaten Labuhan Batu Selatan.

\section{Sumber Data}

Sumber data penelitian ini terdiri dari dua sumber data, yaitu :

a. Sumber Data Primer adalah data yang dibutuhkan dalam penulisan penelitian ini, yaitu Guru Pendidikan Agama SMP Negeri 2 Kecamatan Sei Kanan Kabupaten Labuhan Batu Selatan yang berjumlah 1 orang.

b. Sumber Data Sekunder adalah sumber data pelengkap yang dibutuhkan dalam penelitian ini, yakni kepala Sekolah dan Siswa- Siswi di SMP Negeri 2 Kec. Sei Kanan Kabupaten Labuhan Batu Selatan.

\section{Jenis Penelitian}

Berdasarkan tempat, penelitian ini termasuk penelitian lapangan ${ }^{19}$ yang akan dilakukan di SMP Negeri 2 Kecamatan Sei Kanan Kabupaten Labuhan Batu Selatan. Adapun Jenis penelitian ini menggunakan pendekatan kualitatif yaitu penelitian yang akan dilakukan dengan mengamati fenomena di sekitarnya dan menganalisisnya dengan menggunakan logika ilmiah. ${ }^{20}$ Secara metode, penelitian ini didekatkan dengan deskriftif yaitu penelitian yang berusaha menggambarkan dan menginterpretasikan objek sesuai apa adanya. ${ }^{21}$ Penelitian ini ditentukan dengan pertimbangan bahwa penelitian ini bertujuan untuk menggambarkan bagaimana usaha guru PAI dalam meningkatkan motivasi belajar Pendidikan Agama Islam siswa di SMP Negeri 2 Kecamatan Sei Kanan Kabupaten Labuhan Batu Selatan.

Tujuan penelitian ini termasuk penelitian deskriptif yaitu penelitian yang dilakukan bertujuan untuk mengungkapkan fenomena murni sebagaimana apa adanya. ${ }^{22}$ Penelitian ini ditujukan kepada guru bidang studi Pendidikan Agama Islam di SMP Negeri 2 Kecamatan Sei Kanan Kabupaten Labuhan Batu Selatan.

${ }^{19}$ Suharsimi Arikunto, Prosedur Penelitian Suatu Pendekatan Praktik (Jakarta: Rineka Cipta, 2006), hlm. 10.

${ }^{20}$ Lexy J. Moeleong, Metodologi Penelitian Kualitatif (Bandung: Rosdakarya,1995), hlm. 170.

${ }^{21}$ Sukardi, Metodologi Penelitian Pendidikan Kompetensi dan Praktiknya (Jakarta: Bumi Aksara,2003), hlm. 153.

${ }^{22}$ Suharsimi Arikunto, Op.Cit., hlm. 7. 
Dimana guru sebagai pemberi ilmu pengetahuan kepada siswa/siswi yang akan dilakukan untuk semua kelas yaitu dari kelas VII hingga Kelas IX.

\section{Teknik Pengumpulan Data}

Teknik pengumpulan data yang digunakan dalam penelitian ini adalah :

a. Observasi

Observasi adalah metode pengumpulan data yang menggunakan pengamatan terhadap objek penelitian. Observasi sebagai alat pengumpulan data harus sistematis artinya observasi serta pencatatannya dilakukan menurut prosedur dan aturan -aturan tertentu sehingga dapat diulangi kembali oleh penelitian lain. ${ }^{23}$

Dalam observasi peneliti akan terjun ke lapangan secara langsung tentang motivasi siswa ketika proses pembelajaran Pendidikan Agama Islam berlangsung di SMP Negeri 2 Kecamatan Sei Kanan Kabupaten Labuhan Batu Selatan. Dalam hal ini peneliti melakukan observasi untuk mendapatkan data yang baik.

b. Wawancara

Wawancara merupakan alat pembuktian terhadap informasi atau keterangan yang diperoleh sebelumnya. Teknik wawancara yang digunakan dalam penelitian kualitatif adalah wawancara mendalam. Wawancara mendalam adalah proses memperoleh keterangan untuk tujuan penelitian dengan cara Tanya jawab sambil bertatap muka antara pewawancara dengan orang yang diwawancarai.

Wawancara yang dimaksudkan di sini yaitu mengadakan tanya jawab langsung dengan guru Pendidikan Agama Islam, Kepala Sekolah, Staf tata Usaha, Dan sisiwa/siswi, dengan harapan dan tujuan untuk mendapatkan informasi tentang motivasi siswa dalam proses pembelajaran Pendidikan Agama Islam di SMP Negeri 2 Kecamatan Sei Kanan Kabupaten Labuhan Batu Selatan.

c. Dokumentasi adalah sumber data yang digunakan untuk melengkapi penelitian, baik berupa sumber tetulis, film, gambar (foto), karya-karya monumental, yang semuanya itu memberikan informasi untuk proses penelitian. ${ }^{24}$ Dalam penelitian ini penulis melakukan dokumentasi untuk mengetahui data-data.

\footnotetext{
${ }^{23}$ S. Nasution, Metode Research (Jakarta: Bumi Aksara, 2003), hlm. 107.

${ }^{24}$ Ahmad Nizar Rangkuti, Metode Penelitian Pendidikan, (Bandung: Cita Pustaka Media 2014), hlm. 129.
} 


\section{Teknik Analisis Data}

Dalam hal ini analisis data, ada beberapa langkah yang harus diperhatikan peneliti, antara lain:

a. Reduksi, data yang diperoleh dari lapangan ditulis dalam bentuk uraian yang sangat lengkap dan banyak. Data tersebut dirangkumkan dan dipilih hal-hal yang pokok, dan berkaitan dengan masalah, sehingga memberi gambaran tentang hasil pengamamtan dan wawancara.

b. Deskriftif data, menggunakan data secara sistematis, secara induktif dan deduktif sesuai dengan sistematika pembahasan.

\section{Hasil Penelitian}

\section{Temuan Umum}

a. Sejarah singkat sekolah

SMP Negeri 2 Sei-Kanan Desa Sampean merupakan salah satu SMP yang berstatus Negeri di Desa Sampean. Sekolah ini berdiri pada tahun 1992. Sekolah ini berdiri atas permintaan masyarakat dan bantuan dari pemerintah karena sekolah sebelumnya sangat jauh dari desa Sampean.

b. Letak Geografis Sekolah

Ditinjau dari letak geografisnya SMP Negeri 2 Sei-Kanan Desa Sampean berbatasan dengan:

Sebelah Timur berbatasan dengan rumah penduduk Desa Sampean.

Sebelah Selatan berbatasan dengan sungai besar.

Sebelah Barat berbatasan dengan kebut sawit.

Sebelah Utara berbatasan dengan rumah penduduk Desa Sampean.

c. Visi Misi SMP Negeri 2 Sei-Kanan Desa Sampean

Sesuai dengan cirinya yang mengacu pada sekolah umum, sekolah ini memiliki Visi Misi:

1) Visinya yaitu: Mewujudkan sekolah yang berkualitas di bidang akademik dan extra kurikuler serta dilandasi iman dan taqwa.

2) Misinya yaitu:

a) Mengembangkan sumberdaya secara optimal dalam rangka mempersiapkan siswa berkompetisi di era global.

b) Menciptakan lingkungan sekolah yang asri, bersih, indah, hijau dan nyaman berwawasan.

c) Mewujudkan pendidikan yang menghasilkan lulusan yang berakhlak, kreatif, berfrestasi, berwawasan iptek dan lingkungan.

d. Keadaan Sarana dan Prasarana 
Sarana dan Prasarana di SMP Negeri 2 Kecamatan Sei-kanan Kabupaten Labuhan Batu Selatan, adalah Sebagaimana tertera di bawah ini:

Tabel. 1

Keadaan Sarana dan Prasarana

\begin{tabular}{|l|l|l|}
\hline No & Jenis & Jumlah \\
\hline 1 & Ruang Kepala Sekolah & 1 ruang \\
\hline 2 & Ruang Belajar & 5 ruang \\
\hline 3 & Ruang Penjaga Sekolah & 1 buah \\
\hline 4 & Ruang Guru & 1 buah \\
\hline 5 & Ruang Keterampilan & 1 buah \\
\hline 6 & Ruang Tata Usaha & 1 buah \\
\hline 7 & Ruang BP/BK & 1 buah \\
\hline
\end{tabular}

Sumber: Data SMP Negeri 2 Kec. Sei Kanan

e. Keadaan Guru di SMP Negeri 2 Sei-Kanan Kabupaten Labuhan Batu Selatan.

Tabel. 2

Data Guru Dan Pegawai SMP Negeri 2 Sei-Kanan

\begin{tabular}{|c|l|l|l|l|l|}
\hline NO & \multicolumn{1}{|c|}{ NAMA } & \multicolumn{1}{|c|}{ T.T.L } & \multicolumn{1}{|c|}{ Jabatan } & Gol. & Bidang Studi \\
\hline 1 & H. Suratno, S.Pd & $\begin{array}{l}\text { Galang DS, } \\
21-04-1965\end{array}$ & Kepala Sekolah & IV/a & - \\
\hline 2 & $\begin{array}{l}\text { Ahmad Sauli } \\
\text { Rambe, S.Pd }\end{array}$ & $\begin{array}{l}\text { Sungai } \\
\text { Tolang, 08- } \\
02-1979\end{array}$ & Waka Sek & III/c & Matematika \\
\hline 3 & Ernyda, S. Pd & - & Wali Kelas IX & III/c & $\begin{array}{l}\text { Bahasa } \\
\text { Indonesia }\end{array}$ \\
\hline 4 & $\begin{array}{l}\text { Hj. Rustiana } \\
\text { Hasibuan, BA }\end{array}$ & $\begin{array}{l}\text { Hajoran,15- } \\
03-1956\end{array}$ & Wali Kelas VIII & III/c & PAI \\
\hline 5 & $\begin{array}{l}\text { Darwin Siregar, } \\
\text { S.E }\end{array}$ & $\begin{array}{l}\text { Sitimbulon, } \\
10-11-1969\end{array}$ & Guru & IV/a & $\begin{array}{l}\text { Kewarganegara } \\
\text { an }\end{array}$ \\
\hline 6 & $\begin{array}{l}\text { Niba Hanum Tjg, } \\
\text { S.PdI }\end{array}$ & $\begin{array}{l}\text { Patihe, 26- } \\
09-1979\end{array}$ & Wali Kelas VII ${ }^{\mathrm{A}}$ & III/c & Biologi \\
\hline 7 & $\begin{array}{l}\text { Hariani Ritonga, } \\
\text { S.PdI }\end{array}$ & $\begin{array}{l}\text { Janjimanaha } \\
\text { n, 11-07- }\end{array}$ & Guru & - & Bahasa Inggris \\
\hline
\end{tabular}




\begin{tabular}{|c|c|c|c|c|c|}
\hline NO & NAMA & T.T.L & Jabatan & Gol. & Bidang Studi \\
\hline & & 1990 & & & \\
\hline 8 & $\begin{array}{l}\text { Butet Siregar, } \\
\text { S,Pd }\end{array}$ & $\begin{array}{l}\text { Huta } \\
\text { Godang, 08- } \\
01-1987\end{array}$ & Wali Kelas VIII ${ }^{\mathrm{B}}$ & $\mathrm{III} / \mathrm{c}$ & $\begin{array}{l}\text { Ilmu } \\
\text { Pengetahuan } \\
\text { Sosial } \\
\end{array}$ \\
\hline 9 & $\begin{array}{l}\text { Eva Susanti Tjg, } \\
\text { S.Pd }\end{array}$ & - & Guru & $\mathrm{III} / \mathrm{c}$ & $\begin{array}{l}\text { Ilmu } \\
\text { Pengetahuan } \\
\text { Alam }\end{array}$ \\
\hline 10 & $\begin{array}{l}\text { Siti Aisyah } \\
\text { Hasibuan }\end{array}$ & - & Guru & - & Olah Raga \\
\hline 11 & $\begin{array}{ll}\text { Seri } & \text { Anis } \\
\text { Hasibun } & \\
\end{array}$ & - & Guru & - & - Matematika \\
\hline 12 & $\begin{array}{l}\text { Mara Lolot P. } \\
\text { Siregar }\end{array}$ & - & Tata Usaha & - & - \\
\hline 13 & $\begin{array}{l}\text { Gustina Yanti } \\
\text { Hrp }\end{array}$ & $\begin{array}{l}\text { Parimburan, } \\
17-08-1993\end{array}$ & Tata Usaha & - & - \\
\hline 14 & Roikamil & $\begin{array}{l}\text { Hajoran, 29- } \\
05-1975\end{array}$ & Penjaga Sekolah & - & - \\
\hline
\end{tabular}

Sumber Data: Papan Data Guru di SMP Negeri 2 Kec. Sei Kanan

f. Data Siswa SMP Negeri 2 Sei-Kanan Desa Sampean

Tabel. 3

Jumlah Seluruh Siswa SMP Negeri 2 Sei-Kanan

\begin{tabular}{|l|l|l|l|}
\hline Kelas & LK & PR & Jumlah \\
\hline VII $^{\mathrm{A}}$ & 15 & 12 & 27 \\
\hline $\mathrm{VII}^{\mathrm{B}}$ & 16 & 12 & 28 \\
\hline $\mathrm{VIII}^{\mathrm{A}}$ & 15 & 12 & 27 \\
\hline $\mathrm{VIII}^{\mathrm{B}}$ & 14 & 14 & 28 \\
\hline IX $^{\text {Jumlah }}$ & 10 & 12 & 22 \\
\hline
\end{tabular}

Sumber data: Data dari Admnistrasi SMP Negeri 2 Kec. Sei Kanan

\section{Temuan Khusus}

a. Gambaran motivasi siswa belajar Pendidikan Agama Islam di SMP Negeri 2 Kecamatan Sei Kanan Kabupaten Labuhan Batu Selatan.

Motivasi bagi pelajar dapat mengembangkan aktivitas dan inisiatif, dapat mengarahkan dan memelihara ketekunan dalam kegiatan belajar. Oleh karena itu peneliti melakukan wawancara dan observasi tentang gambaran motivasi 
siswa belajar siswa di SMP Negeri 2 Kecamatan Sei Kanan Kabupaten Labuhan Batu Selatan. Adapun hasil observasi peneliti antara lain, yaitu:

1) Dalam menyelesaikan tugas

Menyelesaikan tugas merupakan suatu pekerjaan yang harus dikerjakan siswa, karena siswa yang rajin mengerjakan tugas ia akan mendapat nilai yang bagus, jadi yang telah peneliti observasi siswa sudah mulai mengerjakan kewajibannya sebagai seorang pelajar yaitu mengerjakan tugas yang diberikan pendidik tersebut, kemudian apabila guru pendidikan Agama Islam memberikan tugas kepada siswa supaya mengerjakannya dirumah dan besok harinya dikumpulkan, apabila ada siswa yang tidak mengerjakan tugasnya diberi sanksi yaitu maju kedepan dan diberi hukuman yang pantas. ${ }^{25}$

Dari hasil wawancara dengan Rafika Aulia ia mengatakan bahwa apabila guru Agama Islam memberikan tugas dan dikerjakan dirumah ia dapat menyelesaikannya besok harinya, akan tetapi sebagian siswa lainnya tidak mengerjakan tugas tersebut, akan tetapi mencontoh tugas siswa yang lain. ${ }^{26}$

2) Dalam mengikuti kompetisi atau saingan

Kompetisi atau saingan merupakan alat yang dapat digunakan untuk meningkatkan motivasi siswa dalam belajar. Adapun hasil observasi peneliti adalah bahwa ketika siswa menglam ikuti kompetisi atau saingan banyak hambatan yang dihadapi siswa seperti: siswa yang intlegensinya kurang menurut hasil observasi peneliti ia merasa malu dengan teman-temannya dikarenakan ia selalu yang terakhir keluar dari ruangan, karena guru pendidikan Agama Islam melakukan kompetisi atau saingan "siapa dapat dia lebih awal keluar dari ruangan",27

3) Dalam menerima hadiah

Hadiah merupakan suatu barang yang dapat meningkatkan motivasi siswa belajar pendidikan Agama Islam.

Adapun hasil observasi peneliti adalah setiap siswa menerima hadiah baik ia berupa barang siswa tersebut pasti sangat cepat menerimanya, karena hadiah berupa barang sangat berharga daripada sebuah pujian, dan yang peneliti lihat siswa tersebut lebih termotivasi untuk belajar, akan tetapi pemberian hadiah ini jarang dilakukan guru Agama Islam. Jadi diberikannya hadiah kepada siswa yang berprestasi atau memilki nilai yang tinggi dan siswa

\footnotetext{
${ }^{25}$ Hasil Observasi Peneliti, Pada Tanggal 23 Juli 2015

${ }^{26}$ Rafika Aulia, Siswa Kelas IX di SMP Negeri 2 Kecamatan Sei Kanan Kabupaten Labuhan Batu Selatan, Wawancara Pada Tanggal 29 Juli 2015.

${ }^{27}$ Hasil Observasi Peneliti, Pada Tanggal 23 Juli 2015
} 
tersebut lebih termotivasi untuk belajar karena menurut siswa hadiah sangat berharga dibandingkan sebuah pujian, jadi untuk mendapatkan sebuah hadiah siswa berusaha dalam belajarnya dengan sunggu-sungguh. ${ }^{28}$

4) Hasrat untuk belajar

Setiap siswa pasti memiliki hasrat untuk belajar dan ada juga yang sama sekali tidak memilki hasrat untuk belajar, dan ada pula yang kurang memiliki hasrat untuk belajar. Jadi disini seorang pendidik harus mampu menggunakan waktu dalam belajar karena Jam pelajaran Pendidikan Agama Islam hanya 2 jam dalam seminggu supaya tercapainya proses pembelajaran yang disiplin atau kondusif guru harus bisa menggunakan waktu yang sedemikian.

Jadi berdasarkan hasil wawancara dengan guru Agama Islam bahwa setiap siswa dan siswi berbeda prestasinya, prilakunya dan cara berpikirnya. Jadi siwa yang demikian itu harus dihadapi, jadi disini guru Agama Islam butuh bantuan dari orang tua yaitu dengan mengadakan rapat dengan orang tua yaitu satu kali dalam sebulan, untuk meningkatkan motivasi siswa dalam belajar, dan kepala sekolah menyuruh guru bidang studi lainnya ikut berpartisipasi dalam kemajuan peserta didik tersebut. ${ }^{29}$

Dari observasi yang dilakukan oleh peneliti bahwa gambaran motivasi siswa dalam belajar Pendidikan Agama Islam dikategorikan sudah cukup bagus, karena guru Agama Islam melakukan berbagai cara untuk mengajar siswa tersebut menjadi anak baik, akan tetapi ada sebagian siswa yang susah untuk diatur dan melawan kepada guru.

b. Hambatan yang dihadapi guru Agama Islam dalam menigkatkan motivasi belajar Pendidikan Agama Islam siswa di SMP Negeri 2 Kecamatan Sei Kanan Kabupaten Labuhan Batu Selatan

Tanggung jawab guru Agama Islam itu cukup berat karena tanggung jawab guru tidak hanya terdapat pada seorang siswa saja, tetapi dalam jumlah siswa yang cukup banyak, seperti jumlah siswa yang ada di SMP Negeri 2 Kec. Sei Kanan tersebut berjumlah 132. Siswa yang jumlah cukup banyak itu tentu saja dari latar belakang kehidupan social yang berbeda- beda. Karenanya, siswa yang berkumpul di sekolah pun memiliki krakteristik yang bernacam- macam, yaitu kepribadian mereka ada yang pendiam, kreatif, malas, rajin, keras kepala,

\footnotetext{
${ }^{28}$ Hasil Observasi Peneliti, Pada Tanggal 23 Juli 2015

${ }^{29}$ Ibu Rustiana Hasibuan, Guru Pendidikan Agama Islam, Wawancara Pada Tanggal 27 Juli 2015
} 
ada yang manja dan sebagainya. Intelektual mereka juga pasti berbeda- beda, ada yang pintar dan ada pula yang kurang pintar. Biologis mereka dengan struktur atau keadaan yang tidak selalu sama. Karena itu, perbedaan siswa pada aspek biologis, intelektual, dan psikologis ini mempengaruhi dalam proses kegiatan belajar mengajar. Siswa yang dengan ciri-ciri mereka masing- masing itu terkumpul di dalam kelas, dan yang mengumpulkannya tentu saja guru atau pengelola sekolah. Banyak sedikitnya jumlah siswa di kelas akan mempengaruhi pengelolaan kelas. Jumlah siswa yang banyak di kelas, misalnya 30 sampai 45 orang, cendrung lebih sukar dikelola, karena lebih mudah terjadi konflik di antara mereka. Hal ini akan berpengaruh terhadap keberhasilan belajar mengajar. Apalagi bila siswa yang dikumpulkan itu sudah terbiasa kurang disiplin.

Sesuai dengan uaraian di atas guru pendidikan Agama Islam di SMP Negeri 2 Kec. Sei Kanan mendapat hambatan dalam meningkatkan motivasi siswa belajar PAI atau tidak tercapainya tujuan proses pembelajaran.

Dari hasil observasi peneliti guru Agama Islam menghadapi berbagai hambatan seperti kurangnya jam mata pelajaran, akan tetapi guru Agama Islam berusaha untuk mengoptimalkan waktu yang sedikit itu yaitu dengan diadakannya les tambahan satu kali dalam seminggu, kemudian meghadapi siswa yang malas mengerjakan tugas, disinilah hambatan yang paling sulit dihadapi guru Agama Islam tersebut, walaupun demikian guru Agama Islam sabar dalam menghadapi siswa yang tidak mengerjakan tugasnya. Dan ada pula siswa yang ribut ketika proses pembelajaran berlangsung, dan keluar masuk dari ruangan, hal ini merupakan mengganggu konsentrasi pembelajaran siswa tersebut. ${ }^{30}$

Dari hasil observasi peneliti apabila ada siswa yang mengganggu teman perempuannya diberi sanksi kepada siswa tersebut, yaitu dipanggil kedepan kelas, kemudian dipanggil ke kanntor dan diproses guru yang bersangkutan tersebut dan adanya panggilan orang tua, karena perbuatan tersebut tidak baik dilakukan siswa. ${ }^{31}$

Menurut hasil wawancara dengan Guru Agama Islam yaitu ibu Rustian Hasibuan, bahwa kurangnya jam mata pelajaran PAI yang disediakan untuk mata pelajaran pendidikan Agama Islam yaitu hanya dua jam dalam per

${ }^{30}$ Hasil Observasi Peneliti, Pada Tanggal 23 Juli 2015.
${ }^{31}$ Hasil Observasi Peneliti, Pada Tanggal 23 Juli 2015. 
minggunya, mengingat pentingnya pelajaran pendidikan Agama Islam di sekolah- sekolah umum, khususnya SMP Negeri 2 Kec. Sei Kanan.

Senada dengan hal di atas ibu Rustiana Hasibuan, juga mengatakan dua jam perminggu itu terlalu sedikit untuk pelajaran pendidikan Agama Islam, kadang-kadang ketika pokok bahasan mata pelajaran tersebut belum selesai diterangkan bel sudah berbunyi (jam pelajaran habis), apa lagi ketika pokok bahasan mata pelajaran Pendidikan Agama Islam tersebut sulit untuk diterangkan, otomatis pokok bahasan tersebut akan dibahas minggu depannya, sementara itu minggu depan kebanyakan siswa banyak yang telah lupa pelajaran sebelumnya, dengan sangat terpaksa seorang pendidik harus mengulangi pokok bahasan tersebut. Maka dua jam pelajaran perminggu tersebut kurang efektif. ${ }^{32}$ Untuk mengantisipasi kurangnya jam mata pelajaran tersebut diadakan les tambahan diluar jam pelajaran yang telah disediakan. ${ }^{33}$

c. Usaha Guru Pendidikan Agama Islam dalam meningkatkan motivasi belajar Pendidikan Agama Islam siswa di SMP Negeri 2 Kecamatan Sei Kananan Kabupaten Labuhan Batu Selatan

Guru Agama Islam sangat berpengaruh terhadap peningkatan motivasi dalam pembelajaran. Jika dihubungkan dengan usaha guru dalam meningkatkan motivasi siswa dalam proses belajar mengajar, maka berbagai faktor yang sangat berpengaruh terhadap hasil pembelajarannya. Seperti latar belakang pendidikan dan tingkat jabatan kemampuan guru untuk memimpin dan dipimpin orientasi propesional guru dan sebagainya. Usaha guru yang dimaksud dalam pembahasan ini adalah usaha guru agama dalam meningkatkan motivasi siswa belajar PAI di SMP Negeri 2 Kec. Sei Kanan Kab. Labuhan Batu Selatan sehingga terjadi interaksi antara guru dan siswa di dalam proses belajar mengajar dengan tujuan untuk mencapai cita-cita atau keinginan dan tujuan pendidikan disekolah tersebut.

Berdasarkan hasil observasi yang peneliti lakukan tentang usaha guru Agama Islam dalam meningkatkan Motivasi belajar Pendidikan Agama Islam sebagai berikut: ${ }^{34}$

1) Pujian

\footnotetext{
${ }^{32}$ Rustiana, Guru Pendidikan Agama Islam SMP Negeri 2 Kec. Sei Kanan Kabupaten Labuhan Batu Selatan, wawancara tanggal 27 Juli 2015.

${ }^{33}$ Rustiana, Guru Pendidikan Agama Islam SMP Negeri 2 Kec. Sei Kanan Kabupaten Labuhan Batu Selatan, wawancara tanggal 27 Juli 2015.

${ }^{34}$ Hasil Observasi Peneliti, Pada Tanggal 23 Juli 2015
} 
Pujian yang tepat untuk membentuk suasana yang menyenangkan dan mempertinggi gairah belajar siswa. Kemudian apabila guru Agama Islam memberikan sebuah pujian kepada siswa gairahnya untuk belajar lebih tinggi lagi.

Berdasarkan hasil wawancara dengan guru Pendidikan Agama Islam tentang pujian, pujian dan respon yang positif yang diberikan kepada siswa yang memilki prestasi, siswa akan merasa bahwa perbuatannya dihargai dan dengan demikian akan menjadi motivasi untuk terus berusaha menunjukkan prestasi yang baik. ${ }^{35}$

Wawancara dengan siswa yaitu Maya Istina menjelaskan guru Agama Islam memberikan dorongan bagi siswa yang mampu menjawab sebuah pertanyaan dan yang mendapat nilai yang bagus diberi pujian agar mahasiswa semangat dalam belajar.

Dari hasil observasi peneliti bahwa dalam memberikan sebuah pujian kepada siswa merupakan hal yang dapat meningkatkan minat belajar siswa tersebut, adapun bentuk pujiannya seperti " bagus" dari memberikan pujian tersebut otimatis siswa akan termotivasi untuk belajar lebih giat lagi, dan yang peneliti observasi apabila siswa diberikan sebuah pujian mukanya langsung berubah, dan ia merasa bangga. ${ }^{36}$

Dari penjelasan diatas dapat disimpulkan untuk meningkatkan motivasi dengan memberikan pujian kepada siswa yang berprestasi maka akan semakin termotivasi untuk mendapatkan prestasi yang baik. Pujian kepada siswa adalah metode yang baik untuk menambah minat siswa untuk belajar.

2) Memberi Ulangan

Ulangan bisa dijadikan sebagai alat motivasi. Siswa akan giat belajar jika mengetahui aka nada ulangan. Siswa mempersiapkan diri dengan belajar jauhjauh hari untuk ulangan. Oleh karena itu, member ulangan merupakan strategi yang cukup baik. Dalam kegiatan proses pembelajaran, ulangan dapat dimanfaatkan guru Pendidikan Agama Islam untuk membangkitkan perhatian siswa terhadap bahan yang diberikan di ruangan.

Hasil observasi yang peneliti lakukan bahwa dalam memberikan ulangan ini guru Agama Islam mengumumkan kepada siswa bahwa besok akan diadakannya ulangan, baik ia berupa lisan dan tulisan, supaya siswa

\footnotetext{
${ }^{35}$ Rustiana, Guru Pendidikan Agama Islam SMP Negeri 2 Kec. Sei Kanan Kabupaten Labuhan Batu Selatan, wawancara tanggal 27 Juli 2015.

${ }^{36}$ Hasil Obsevasi Peneliti, Pada Tanggal 23 Juni 2015.
} 
mempersiapkan diri untuk menjawab pertanyaan dari guru Agama Islam tersebut. $^{37}$

Dengan hasil wawancara dengan Guru Agama Islam yaitu iu Rustiana Hasibua tentang member ulangan kepada siswa, beliau menjelaska bahwa, pemberian ulangan, ulangan ini berbentuk, lisan dan tulisan para siswa selalu dilaksanakan. Pemberian ulangan dilakukan dua kali sampai tiga kali dalam satu semester hal ini dilakukan agar para mahasiswa focus terhadap pelajaran yang telah disampaikan oleh Guru Pendidikan Agama Islam, sehingga para siswa termotivasi untuk belajar. ${ }^{38}$

Dari uraian di atas dapat diketahui guru Agama Islam memberikan ulangan. Ulangan dapat diberikan pada akhir kegiatan pembelajaran adalah salah satu upaya yang dapat meningkatkan motivasi dan minat belajar siswa sehingga ulangan merupakan motivasi belajar siswa, ulangan dilakukan pada akhir kegiatan pengajaran atau pertengahan semester.

3) Memberi Angka atau Penelian

Sesuai dengan hasil wawancara dengan guru Pendidikan Agama Islam, beliau menjelaskan bahwa " dalam upaya member motivasi kepada para siswa, saya selalu memberikan bagi siswa yang aktif bertanya, yang mengerjakan tugas dan mampu menjawab pertanyaan yang saya berikan.

Sesuai dengan hasil observasi peneliti guru Agama Islam selalu memberikan angka atau penilaian, pemberian angka bagi siswa agar siswa mengetahui sejauh mana ia telah mampu menguasai materi pelajaran. ${ }^{39}$

Angka yang dimaksud di atas adalah sebagai symbol atau nilai dari hasil aktivitas belajar siswa. Pemberian angka bagi siswa biasanya bervariasi sesuai hasil tes atau ulangan mereka. Disamping symbol nilai angka merupakan alat motivasi yang cukup memberikan perkembangan kepada siswa dalam mempertahankan prestasi belajar. Angka inilah yang akan lebih mendorong memotivasi siswa untuk lebih giat belajar, nilai ini biasanya terdapat pada raport siswa tersebut.

4) Mengetahui Hasil

Hasil belajar dipengaruhi oleh pengalaman subyek belajar dengan dunia fisik dengan lingkungan. Rasa ingin tahu merupakan potensi diri setiap manusia. Dorongan ingin tahu menyebabkan seseorang dengan mengetahui hasil

\footnotetext{
${ }^{37}$ Hasil Observasi Peneliti, Pada Tanggal 23 Juni 2015

${ }^{38}$ Rustiana, Guru Pendidikan Agama Islam SMP Negeri 2 Kec. Sei Kanan Kabupaten Labuhan Batu Selatan, wawancara tanggal 27 Juli 2015.

${ }^{39}$ Hasil Observasi Peneliti, Pada Tanggal 23 Juni 2015
} 
pekerjaan apabila terjadi kemauan, akan mendorong siswa untuk lebih giat belajar, maka ada motivasi pada diri siswa untuk terus belajar dengan berharap hasilnya terus meningkat.

Hasil wawancara peneliti dengan Guru Pendidikan Agama Islam mengatakan bahwa " hasil dari tugas-tugas yang diberikan pada siswa akan diperlihatkan kepada siswa supaya siswa mengetahui hasil yang dicapai dan sebagai bukti usaha yang telah dilakukan selama ini. ${ }^{40}$

Dari hasil observasi di atas dapat diketahui bahwa memperlihatkan hasil yang dicapai siswa merupakan salah satu upaya yang dapat memotivasi siswa meningkatkan minat belajar siswa pada mata pelajaran Pendidikan Agama Islam. ${ }^{41}$

5) Hukuman

Hukuman merupakan tindakan pendidik terhadap anak didik karena melakukan kesalahan, dan dilakukan agar anak didik tidak lagi melakukannya. Sebagai salah satu upaya dalam memotivasi siswa pemberian hukuman bagi siswa yang melanggar peraturan sekolah atau sebagai hukuman bagi siswa yang tidak mengerjakan tugas.

Wawancara dengan Guru Pendidikan Agama Islam menjelaskan bahwa" pemberian hukuman bagi siswa yang melanggar tata tertib dan tidak melaksanakan segala tugas yang diberikan oleh Guru Agama Islam maka tidak akan dikeluarkan hasil ujian dan tidak di ikutkan dalam ujian semester sebelum siswa melengkapi tugas-tugasnya. Kemudian adanya panggilan orang tua, demi perubahan peserta didik tersebut. ${ }^{42}$

Berdasarkan hasil wawancara dan observasi yang dilakukan penulis menimpulkan bahwa dalam usaha guru Pendidikan Agama Islam dalam memotivasi siswa guru Pendidikan Agama Islam melakukan berbagai cara untuk meningkatkan minat belajar siswa.

\section{Analisis Hasil Penelitian}

Analisis hasil penelitian mengenai Usaha guru Agama Islam dalam meningkatkan Motivasi Belajar siswa PAI di SMP Negeri 2 Kec. Sei Kanan Kabupaten Labuhan Batu Selatan, dan berdasarkan observasi dan wawancara yang peneliti lakukan dengan Guru PAI, Kepala Sekolah dan Siswa dapat

\footnotetext{
${ }^{40}$ Rustiana, Guru Pendidikan Agama Islam SMP Negeri 2 Kec. Sei Kanan Kabupaten Labuhan Batu Selatan, wawancara tanggal 27 Juli 2015.

${ }^{41}$ Hasil Observasi Peneliti, Pada Tanggal 23 Juni 2015.

${ }^{42}$ Rustiana, Guru Pendidikan Agama Islam SMP Negeri 2 Kec. Sei Kanan Kabupaten Labuhan Batu Selatan, wawancara tanggal 27 Juli 2015
} 
dikategorikan baik, disebabkan adanya usaha guru Agama Islam dalam meningkatkan motivasi siswa belajar PAI, guru bidang studi lainnya dan juga kepala sekolah.

Dengan demikian masih banyak siswa yang kurang termotivasi dalam belajar PAI dikarenakan adanya siswa yang ribut dalam ruangan, dan siswa yang ribut tersebut mengganggu konsentrasi siswa yang lain dalam proses pembelajaran tersebut, dan ada pula yang mengantuk, akibat dari siswa yang mengantuk ini yaitu dikarenakan siswa tersebut ada yang kecapean dan ada pula yang begadang pada malam hari, jadi sebaiknya sebagai orang tua harus ikut serta memantau siswa tersebut dalam kesehariannya di rumah. keluar masuk dari ruangan dan kurangnya jam mata pelajaran Pendidikan Agama Islam.

Dalam mengatasinya yaitu, apabila ada siswa yang ribut dalam proses pembelajaran sebaiknya guru berhenti sejenak, setelah siswa tersebut tidak ribut maka pembelajaran dilanjutkan. Dan guru jangan memanggil siswa apabila dalam proses pembelajaran berlangsung supaya tidak ada siswa yang keluar masuk kelas.

\section{Kesimpulan}

\section{Penutup}

Berdasarkan hasil penelitian di lapangan dan pembahasan ada beberapa kesimpulan dalam Bab ini antara lain:

a. Gambaran Motivasi Belajar PAI siswa di SMP Negeri 2 Kecamatan Sei Kanan Kabupaten Labuhan Batu Selatan yaitu dengan menyelesaikan tugas, mengikuti kompetisi/saingan, menerima hadiah, hasrta untuk belajar. Para siswa melaksanakannya dengan baik, oleh karena itu apabila menelesaikan tugas siswa mengerjakannya dirumah, kemudian mengikuti kompetisi/saingan siswa melakukannya dengan tertib, kemudian apabila dalam menerima hadiah siswa lebih termotivasi untuk belajar.

b. Hambatan yang dihadapi Guru Pendidikan Agama Islam dalam meningkatkan motivasi siswa belajar pendidikan Agama Islam di SMP Negeri 2 Kecamatan Sei Kanan Kabupaten Labuhan Batu Selatan ada beberapa hambatan dihadapi Guru Pendidikan Agama Islam yaitu kurangnya jam mata pelajaran, akan tetapi guru Agama Islam berusaha untuk mengoptimalkan waktu yang sedikit itu yaitu dengan diadakannya les tambahan satu kali dalam seminggu, kemudian meghadapi siswa yang malas mengerjakan tugas, disinilah hambatan yang paling sulit dihadapi guru Agama Islam tersebut, walaupun demikian guru Agama Islam sabar dalam menghadapi siswa yang 
tidak mengerjakan tugasnya. Dan ada pula siswa yang ribut ketika proses pembelajaran berlangsung, dan keluar masuk dari ruangan, hal ini merupakan mengganggu konsentrasi pembelajaran siswa tersebut

c. Usaha yang dilakukan Guru Pendidkan Agama Islam dalam meningkatkan motivasi belajar Pendidikan Agama Islam siswa di SMP Negeri 2 Kecamatan Sei Kanan Kabupaten Labuhan Batu Selatan yaitu: memberikan pujian, memberikan ulangan, memberikan angka atau penilaian, mengetahui hasil dan memberikan keopada siswa tersebut, suoaya lebih termotivasi dalam belajarnya.

\section{Saran-saran}

Adapun saran-saran yang dapat peneliti sarankan adalah:

a. Guru PAI sebagai pendidik harus terus menerus memberikan Motivasi kepada siswa tersebut agar cara belajar siswa itu berubah, dan memberikan nasehat kepada siswa yang kurang berprestasi. Kemudian orang tua dan guru komunikasinya harus baik, supaya tercapainya apa yang diinginkan.

b. Guru PAI sebagai tenaga Pendidikan harus benar-benar memperdalam dan mengaflikasikan model-model pembelajaran aktual pada mata pelajaran pe

c. Kepada siswa SMP Negeri 2 Ke. Sei Kanan Kabupaten Labuhan Batu Selatan apa bila dalam proses belajar mengajar berlangsung supaya lebih memperhatikan guru yang mengajar dan cara belajarnya lebih ditingkatkan lagi, dan siswa harus merasa berterima kasih kepada guru Agama Islam karena ia sudah susah payah dalam memberikan pelajaran dan guru agama Islam tidak pernah mengeluh apabila ada murid yang bandal akan tetapi iamenghadapinya dengan sabar.

d. Kepala Sekolah, Guru Agama Islam dan dengan bidang studi yang lain harus sama-sama memperhatikan siswa tersebut dilingkungan sekolah maupun di luar sekolah. Dan harus ada komunikasi dengan orang tua siswa tersebut.

\section{Referensi}

Ahmad Nizar Rangkuti, Metode Penelitian Pendidikan, Bandung: Cita Pustaka Media 2014.

AS. Hornby, Oxfordlearnes Pocket Dictionary, New York: Oxford University Press, 1995.

Azhar Arsyad, Media Pembelajaran, Jakarta: Raja Grafindo Persada,1996. 
Baharuddin, Aktualisasi Psikologi Islam, Yogyakarta: PT. Pustaka Pelajar, 2005.

Jalaluddin, Psikologi Agama, Jakarta: PT. Raja Grafindo Persada, 2010.

Jhon, M. Echols dan Hasan Shadaly, Kamus Inggris Indonesia, Jakarta: Gramedia Pustaka Utama 1986.

Lexy J. Moeleong, Metodologi Penelitian Kualitatif, Bandung: Rosdakarya,1995.

Oemar Hamalik, Kurikulum dan Pembelajaran, Bandung : Bumi Aksara, 2008.

Pusat Bahasa Departemen Pendidikan Nasional, Kamus Besar Bahasa Indonesia Edisi Ke -3, Jakarta: Balai Pustaka, 2001.

Ramayulis, Ilmu Pendidikan Islam, Jakarta: Kalam Mulia, 2008.

S. Nasution, Didaktik Asas- asas Mengajar, PT: Jemmars Bandung, 1982.

S. Nasution, Metode Research, Jakarta: Bumi Aksara, 2003.

Sardiman, Interaksi Motivasi Belajar Mengajar, Jakarta : Rajawali Pres, 2009

Soetjipto dan Raflis Kosasi, Profesi Keguruan, Jakarta: Rineka Cipta, 2000.

Suharsimi Arikunto, Prosedur Penelitian suatu Pendekatan Praktik, Jakarta: Rineka Cipta, 2006.

Sukardi, Metodologi Penelitian Pendidikan Kompetensi dan Praktiknya, Jakarta: Bumi Aksara,2003.

Syaiful Bahri Djamarah, Guru dan Anak Didik dalam Interaksi Edukatif, Jakarta: PT. Asdi Mahasatya, 2005.

Tim Penyusun, Al-Qur'an dan Terjemahannya, Departemen Agama RI

Zakiah Darajat, Pendidikan Islam dalam Keluarga dan Sekolah, Jakarta: PT Remaja Rosdakarya, 1994. 